\title{
A POSSIBILIDADE DO PRINCÍPIO DA NÃO REGRESSÃO NO DIREITO AMBIENTAL BRASILEIRO ${ }^{1}$
}

\author{
LA POSIBILIDAD DEL PRINCÍPIO DE NO REGRESIÓN EM EL DERECHO \\ AMBIENTAL DE BRASIL
}

Jaqueline Moretti Quintero²

\begin{abstract}
SUMÁRIO: Introdução; 1. Normas E Doutrinas Sustentadoras do Princípio da Não Regressão; 2. O Princípio da Não Regressão do Direito Ambiental no Direito Internacional; 3. O Princípio da Não Regressão como Tutela do Direito Ambiental Brasileiro; Considerações Finais; Referências das Fontes Citadas.
\end{abstract}

RESUMO: Este artigo deteve-se a investigar de que modo o "Princípio da Não Regressão" poderá auxiliar de forma efetiva na manutenção e conservação do meio ambiente, procurando equipará-lo a princípios fundamentais na Constituição Brasileira. A pesquisa realizada encontrou amparo também em legislações estrangeiras que já tiveram aplicações relacionadas ao Princípio da Não Regressão como norma positivada em sua legislação ou decisões judiciais que possam firmar tal entendimento. Torna-se primordial o avanço das decisões ambientais que sustentem à progressão normativa para a conservação do meio ambiente, priorizando os interesses difusos. A metodologia utilizada no desenvolvimento da pesquisa compreende o método cartesiano quanto à coleta de dados e no relatório final, o método indutivo com as técnicas do referente, da categoria, dos conceitos operacionais, da pesquisa bibliográfica e do fichamento.

Palavras-chave: Direito Ambiental; Meio Ambiente, Princípio da Não Regressão.

RESÚMEN: Esto artículo se intentó investigar de qué modo el "Principio de la No Regresión" podría auxiliar de forma efectiva en la manutención y conservación

\footnotetext{
1 Parte do presente artigo integra a dissertação: QUINTERO, Jaqueline Moretti. O princípio da "não regressão" no direito ambiental como forma de tutela ao meio ambiente. Itajaí: PPCJ/UNIVALI, 2014.

2 Possui graduação em Direito e Administração pela UNIVALI, Mestre em Ciência Jurídica (UNIVALI) e aluna do Curso de Doutorado em Ciência Jurídica - CDCJ/PPCJ da UNIVALI; Linha de Pesquisa: Estado, Transnacionalidade e Sustentabilidade. E-mail: jaquemoretti@hotmail.com
} 
QUINTERO, Jaqueline Moretti. A possibilidade do princípio da não regressão no Direito Ambiental Brasileiro. Revista Eletrônica Direito e Política, Programa de Pós-Graduação Stricto Sensu em Ciência Jurídica da UNIVALI, Itajaí, v.10, n.1, edição especial de 2015. Disponível em: www.univali.br/direitoepolitica - ISSN 1980-7791.

del medio ambiente, procurando equipararlo a principios fundamentales en la Constitución Brasileña. La investigación realizada encontró amparo también en legislaciones extranjeras que ya tenían aplicaciones relacionadas al Principio de la No Regresión como norma positivada en su legislación o decisiones judiciales que pudiesen corroborar tal entendimiento. Se convierte en fundamental el avance de las decisiones ambientales que apoyan el avance normativo para la conservación del medio ambiente, dando prioridad a los intereses generales.

Palabras clave: Derecho Ambiental; Medio Ambiente Principio de la No Regresión.

\section{INTRODUÇÃO}

O Direito Ambiental atualmente atinge dimensões de tal modo expressivas, evocando apoio em fundamentos jurídicos constitucionais de forma evolutivamente necessária ao bem estar social, apresentando alternativas de consolidação com intenções acautelarias, para que possa solidificar-se com a proximidade de tentativa de manter o meio ambiente ecologicamente equilibrado e à sadia qualidade de vida do homem.

Para que tal evolução possa ocorrer no âmbito material e processual, é necessário compreender a importância do Direito Ambiental dentro das normas jurídicas nacionais e internacionais e encontrar demonstrações jurídicas nas quais o direito esteja qualificado como direito fundamental. Uma vez assim identificado no âmbito do ordenamento jurídico à qual está inserido, ter-se-á melhores condições de preservar seu status e efetivação legal enquanto norma de direito fundamental para a conservação da validade dos direitos do homem.

Faz-se assim deveras importante a sustentação do direito do homem ao meio ambiente de forma intangível como os demais direitos considerados fundamentais para a conservação da sadia qualidade de vida e dignidade do homem.

A qualificação do direito ambiental como direito fundamental é de suma importância para que sua identificação possa ser caracterizada de maneira adequada e, assim, devida e efetivamente utilizada, seja no âmbito do direito brasileiro como em âmbito internacional, através das legislações existentes nos 
QUINTERO, Jaqueline Moretti. A possibilidade do princípio da não regressão no Direito Ambiental Brasileiro. Revista Eletrônica Direito e Política, Programa de Pós-Graduação Stricto Sensu em Ciência Jurídica da UNIVALI, Itajaí, v.10, n.1, edição especial de 2015. Disponível em: www.univali.br/direitoepolitica - ISSN 1980-7791.

diversos países e as normas previstas em várias convenções e pactos internacionais.

\section{NORMAS E DOUTRINAS SUSTENTADORAS DO PRINCÍPIO DA NÃO REGRESSÃO}

O Direito Ambiental tem como objetivo, proteger, promover e evitar a deterioração do ambiente, devendo assim restringir o retrocesso que representa uma infração aos direitos humanos e uma violação aos direitos fundamentais, como bem justifica Carlos Alberto Molinaro ${ }^{3}$.

Em casos relacionados ao meio ambiente algumas ações de prevenção, precaução ou mesmo de repressão podem atingir mais de um país ou mesmo alcançar proporções difíceis de mensurar a agressão como a contaminação da água do mar, para as quais é necessário identificar as legislações vigentes nos respectivos Estados afetados e, de que forma, poderão ser empregadas no caso contrato.

No entendimento de Michel Prieur" "No caso de conflito entre uma lei e a Convenção ou entre uma e outra convenção e a convenção dos direitos humanos, é o texto mais benéfico ao meio ambiente que deverá ser aplicado".

Ensina, no entanto, Michel Prieur ${ }^{5}$ que nas normas de Direito Ambiental interno, existe em alguns países, uma "crescente regressão", que é muitas vezes, falaciosa. Ela se dá por alterações relacionadas às regras de procedimento, reduzindo a magnitude dos direitos à informação e à participação do público, sob o artifício de tratar-se de avaliação de procedimentos; ela ocorre, também, pelas alterações substanciais ou mudanças feitas nas regras de Direito Ambiental,

\footnotetext{
3 MOLINARO, Carlos Alberto. Direito Ambiental: proibição de retrocesso. p. 68.

4 PRIEUR, Michel. O Princípio da "Não Regressão" no Coração do Direito do Homem e do Meio Ambiente. In: Revista Novos Estudos Jurídicos, vol. 17, n. 1, p. 06-17/jan-abr. 2012. Disponível em: <www.univali.br/nej>. Acesso em: 23 ago, 2013. p. 9.

5 PRIEUR, Michel. Princípio da proibição de retrocesso ambiental. In: Comissão de meio ambiente, defesa do consumidor e fiscalização e controle. Princípio da proibição de retrocesso ambiental. Brasília: Senado Federal, 2012. p. 13.
} 
QUINTERO, Jaqueline Moretti. A possibilidade do princípio da não regressão no Direito Ambiental Brasileiro. Revista Eletrônica Direito e Política, Programa de Pós-Graduação Stricto Sensu em Ciência Jurídica da UNIVALI, Itajaí, v.10, n.1, edição especial de 2015. Disponível em: www.univali.br/direitoepolitica - ISSN 1980-7791.

abreviando ou "transformando em inoperantes" as regras em vigor.

Uma vez que na maioria dos documentos assinados pelas nações para convencionar o que se considerou estabelecer enquanto direitos e garantias aos seus povos e respectivos Estados, tentando estabelecer critérios unânimes para apaziguar diferenças estre os povos de diversos países do mundo criando critérios de unificação e padronização para que esses países pudessem progredir no estabelecimento e cumprimento de normativas que valorizassem a igualdade, a liberdade e a dignidade da pessoa humana, o meio ambiente raramente é mencionado especificamente para sua preservação.

Assim o é, que se faz necessário identificar primeiramente o que seria considerado um direito fundamental, de que forma este direito está posicionado em determinada convenção, declaração ou pacto (compartilhado por vários países) e como aproximar tal direito fundamental do meio ambiente e sua preservação e conservação de tal forma que o meio ambiente possa ser considerado um direito fundamental. Essa aproximação do meio ambiente por intermédio do direito ambiental para a equivalência de direito fundamental ao homem é, por algumas vezes, presumida para que possa ter sua validade jurídica. O que se entende, aqui, por presumir é o entendimento de que o meio ambiente e sua conservação, com acesso ao ar respirável ao homem, água potável, alimentos sem toxinas e todos esses recursos em quantidade suficiente para atender à população mundial e, futuramente atender às gerações que estão por vir, possa interferir diretamente no direito à sadia qualidade de vida que o ser humano precisa ter, como prevê o artigo 225 da Constituição da República Federativa do Brasil.

De tal modo, quer-se atingir da maneira mais clara, legal e justificada a necessidade de definir o meio ambiente como direito fundamental, para que este, assim que reconhecido como tal pelo maior número possível de países que adotam em seu ordenamento jurídico a existência e garantias dos direitos fundamentais ao homem, de forma a garantir a importância da preservação e conservação do meio ambiente, através das convenções, declarações e pactos já existentes entre diversas nações, para que atingir assim a preservação também 
QUINTERO, Jaqueline Moretti. A possibilidade do princípio da não regressão no Direito Ambiental Brasileiro. Revista Eletrônica Direito e Política, Programa de Pós-Graduação Stricto Sensu em Ciência Jurídica da UNIVALI, Itajaí, v.10, n.1, edição especial de 2015. Disponível em: www.univali.br/direitoepolitica - ISSN 1980-7791.

da sadia qualidade de vida do homem para as atuais e futuras gerações.

Como informado anteriormente, tem-se que desenvolver o entendimento da tese de que o direito ambiental é considerado um direito fundamental para que, juridicamente no âmbito das Convenções Internacionais, que assim não o prevejam, possam ampará-lo e tutelá-lo tal como os demais direitos fundamentais, auxiliando nas decisões pertinentes às atividades relacionadas à conservação e preservação do meio ambiente em sua universalidade como assim se promove.

Sendo assim, pode-se verificar nas Convenções Internacionais, como o direito fundamental ao homem é delimitado e amparado como instrumento normativo para as nações convenentes a determinado documento internacional e sua importância na normativa interna desse país.

A Declaração Universal dos Direitos Humanos, de 1948, possui em seu preâmbulo, duas considerações iniciais que vertem à necessidade de observar-se mais atentamente de que forma tão importante a Declaração pode auxiliar na fundamentação legal do Direito Ambiental em âmbito internacional. Tais considerações apresentam pontualmente:

Primeiramente, "considerando que o reconhecimento da dignidade inerente a todos os membros da família humana e de seus direitos iguais e inalienáveis é o fundamento da liberdade, da justiça e da paz no mundo." ${ }^{6}$

Nesse primeiro momento, reconhece que a dignidade a todos os homens e a igualdade entre esses mesmos homens é um direito inalienável e, como tal, considerado fundamental.

E, na continuidade das considerações:

Considerando que os povos das Nações Unidas reafirmaram, na Carta, sua fé nos direitos humanos fundamentais, na dignidade e no valor da pessoa humana e na igualdade de

6 NAÇÕES UNIDAS. Declaração Universal dos Direitos Humanos de 10 de Dezembro de 1948. Assembléia Geral das Nações Unidas em 10 de dezembro de 1948. Disponível em: <http://portal.mj.gov.br/sedh/ct/legis_intern/ddh_bib_inter_universal.htm>. Acesso em 06 mar.2014. 
QUINTERO, Jaqueline Moretti. A possibilidade do princípio da não regressão no Direito Ambiental Brasileiro. Revista Eletrônica Direito e Política, Programa de Pós-Graduação Stricto Sensu em Ciência Jurídica da UNIVALI, Itajaí, v.10, n.1, edição especial de 2015. Disponível em: www.univali.br/direitoepolitica - ISSN 1980-7791.

direitos dos homens e das mulheres, e que decidiram promover o progresso social e melhores condições de vida em uma liberdade mais ampla. ${ }^{7}$

Deste modo se enaltece a promoção do progresso social e a melhor condição de vida ao homem, utilizando a garantia dada ao direito fundamental para que seja assim preservado como direito já conquistado e garantido por normativas inspiradas por fatos históricos que puderam permitir tal evolução nas conquistas civilizatórias do mundo contemporâneo, permitindo-se a expetativa positiva de manutenção de direitos que permitirão também a progressão social e respectivas garantias para as atuais e futuras gerações.

Trata-se, portanto, de um entendimento progressista sobre as normas instauradas para que não haja retrocesso aos direitos adquiridos até o momento no que tange à preservação do meio ambiente. O princípio da não regressão, consoante a esta preocupação da constante progressão dos direitos humanos, impõe uma regra de impedimento ao Poder Público para que as conquistas impetradas para a proteção do meio ambiente não sejam dirimidas ou olvidadas, como ensina Michel Prieur ${ }^{8}$ :

Utilizaremos, pois, a fórmula do "princípio da não regressão", para demonstrar que não é uma simples cláusula ou mera regra, mas sim, um verdadeiro princípio, é também a expressão de um dever de não regressão imposto ao Poder Público.

Tratando-se o Princípio da não Regressão como prevenção ao não retrocesso legislativo para a segurança e bem estar do homem, tratando o meio ambiente como direito fundamental ao homem, é que se pode, através de convenções internacionais buscar o entendimento da garantia dos direitos fundamentais, inserindo-se nesse diapasão o meio ambiente, como forma de garantir ao homem uma sadia qualidade de vida através da preservação e conservação do meio ambiente para si e sua família. De tal forma, prevê a Declaração Universal

\footnotetext{
7 NAÇÕES UNIDAS. Declaração Universal dos Direitos Humanos de 10 de Dezembro de 1948. Assembléia Geral das Nações Unidas em 10 de dezembro de 1948. Disponível em: $<$ http://portal.mj.gov.br/sedh/ct/legis_intern/ddh_bib_inter_universal.htm>. Acesso em 06 mar.2014.

8 PRIEUR, Michel. O Princípio da "Não Regressão" no Coração do Direito do Homem e do Meio Ambiente. In: Revista Novos Estudos Jurídicos, p. 8.
} 
QUINTERO, Jaqueline Moretti. A possibilidade do princípio da não regressão no Direito Ambiental Brasileiro. Revista Eletrônica Direito e Política, Programa de Pós-Graduação Stricto Sensu em Ciência Jurídica da UNIVALI, Itajaí, v.10, n.1, edição especial de 2015. Disponível em: www.univali.br/direitoepolitica - ISSN 1980-7791.

dos Direitos Humanos que:

Artigo XXII - Toda pessoa, como membro da sociedade, tem direito à segurança social e à realização, pelo esforço nacional, pela cooperação internacional e de acordo com a organização e recursos de cada Estado, dos direitos econômicos, sociais e culturais indispensáveis à sua dignidade e ao livre desenvolvimento da sua personalidade. ${ }^{9}$ E reforça que:

Artigo XVIII - Toda pessoa tem direito a uma ordem social e internacional em que os direitos e liberdades estabelecidos na presente Declaração possam ser plenamente realizados.

Assim, espera-se não somente de seu país, mas também com o entendimento e a cooperação dos países que pactuaram com tal declaração, que o direito à segurança social, aqui entendido como a promoção do bem estar e a coesão social, e à realização dos direitos econômicos, sociais e culturais, entendidos aqui como indispensáveis à dignidade do homem, possam ser inseridos em seu contexto social, percebendo a importância da conservação do meio à qual o homem que vive em sociedade está exposto para que possa atingir tais direitos econômicos, sociais e culturais. Se não há um ambiente que possa garantir um bem estar mínimo que preserve sua saúde física e mental, mais difícil será para atingir demais direitos que garantirão sua dignidade. O mínimo existencial está diretamente ligado à qualidade do meio ambiente como garantia do direito fundamental do meio ambiente sadio e à dignidade da pessoa humana.

A importância dada à preservação do meio ambiente no âmbito do direito ambiente e constitucional, invocando o Princípio da não Regressão para a sustentação desse direito, traduz a relevância impeditiva do não retrocesso para o direito ambiental como direito fundamental ao homem, garantido nas constituições democráticas no Estado de Direito Contemporâneo e, amplamente abarcado por documentos e convenções internacionais mais importantes, como é o caso do que está previsto no documento da Conferência das Nações Unidas

\footnotetext{
9 NAÇÕES UNIDAS. Declaração Universal dos Direitos Humanos de 10 de Dezembro de 1948. Assembléia Geral das Nações Unidas em 10 de dezembro de 1948. Disponível em: <http://portal.mj.gov.br/sedh/ct/legis_intern/ddh_bib_inter_universal.htm>. Acesso em 06 mar.2014.
} 
QUINTERO, Jaqueline Moretti. A possibilidade do princípio da não regressão no Direito Ambiental Brasileiro. Revista Eletrônica Direito e Política, Programa de Pós-Graduação Stricto Sensu em Ciência Jurídica da UNIVALI, Itajaí, v.10, n.1, edição especial de 2015. Disponível em: www.univali.br/direitoepolitica - ISSN 1980-7791.

sobre o Desenvolvimento Sustentável ${ }^{10}$ :

90. Ressaltamos a necessidade de continuar examinando periodicamente o ambiente em mudança da Terra e seus efeitos sobre o bem estar dos seres humanos, e neste sentido a olhemos com beneplácito iniciativas como o processo das informações "Perspectivas do Meio Ambiente Mundial", cujo objetivo é reunir informação e avaliações do meio ambiente e fomentar a capacidade nacional e regional para apoiar a adoção das decisões informadas.

Apresenta tal documento a recondução do comprometimento em acompanhar o desenvolvimento e consequências desse desenvolvimento ocorrido no planeta, para que a informação de seus efeitos possa auxiliar a tomada de decisões sobre a preservação do meio ambiente. O referido documento reforça ainda sobre a importância da participação de cientistas dos países desenvolvidos e em desenvolvimento sobre os processos de avaliação do desenvolvimento sustentável e o meio ambiente:

279. Encorajamos a participação e a representação de homens e mulheres cientistas e investigadores de países desenvolvidos e em desenvolvimento nos processos relacionados com a avaliação e o seguimento mundial do meio ambiente e o desenvolvimento sustentável, com o propósito de fortalecer as capacidades nacionais e a qualidade da investigação para os processos de tomada de decisões e formulações políticas. ${ }^{11}$

O Pacto Internacional sobre os Direitos Econômicos, Sociais e Culturais das

10 NAÇÕES UNIDAS. Conferência das Nações Unidas sobre o Desenvolvimento Sustentável. EI futuro que queremos. Rio de Janeiro, junho de 2012. Disponível em: <https://rio20.un.org/sites/rio20.un.org/files/a-conf.216-l-1_spanish.pdf.pdf.> Acesso em 10 abr.2014. Texto original: Subrayamos la necesidad de seguir examinando periódicamente el entorno cambiante de la Tierra y sus efectos sobre el bienestar de los seres humanos, y en este sentido acogemos con beneplácito iniciativas como el proceso de los informes "Perspectivas del Medio Ambiente Mundial", cuyo objetivo es reunir información y evaluaciones del medio ambiente y fomentar la capacidad nacional y regional para apoyar la adopción de decisiones informadas. (Livre tradução da autora).

11 NAÇÕES UNIDAS. Conferência das Nações Unidas sobre o Desenvolvimento Sustentável. EI futuro que queremos. Rio de Janeiro, junho de 2012. Disponível em: <https://rio20.un.org/sites/rio20.un.org/files/a-conf.216-l-1_spanish.pdf.pdf.> Acesso em 10 abr.2014. Texto original: 279. Alentamos la participación y la representación de hombres y mujeres científicos e investigadores de países desarrollados y en desarrollo en los procesos relacionados con la evaluación y el seguimiento mundiales del medio ambiente y el desarrollo sostenible, con el propósito de fortalecer las capacidades nacionales y la calidad de la investigación para los procesos de toma de decisiones y formulación de políticas. (Livre tradução da autora). 
QUINTERO, Jaqueline Moretti. A possibilidade do princípio da não regressão no Direito Ambiental Brasileiro. Revista Eletrônica Direito e Política, Programa de Pós-Graduação Stricto Sensu em Ciência Jurídica da UNIVALI, Itajaí, v.10, n.1, edição especial de 2015. Disponível em: www.univali.br/direitoepolitica - ISSN 1980-7791.

Nações Unidas de 1966 assevera em seu artigo 5012:

Artigo 50 - 2. Não pode ser admitida nenhuma restrição ou derrogação aos direitos fundamentais do homem reconhecidos ou em vigor, em qualquer país, em virtude de leis, convenções, regulamentos ou costumes, sob o pretexto de que o presente Pacto não os reconhece ou reconhece-os em menor grau.

O citado Pacto reforça a importância da garantia dos direitos fundamentais ao homem para segurança de todos, independente da interpretação que lhe for dada, no sentido de reconhecer atividades que possam ir contra o que está estabelecido no referido Pacto ou de obstruir os direitos e liberdades individuais. Não se admite, também no Pacto Internacional sobre os Direitos Econômicos, Sociais e Culturais, retrocesso de qualquer natureza que possa atingir os direitos fundamentais obtidos pela sociedade contemporânea.

Ainda prevê, dito Pacto, em seu Artigo 11. ${ }^{\circ}, 1^{13}$ que os Estados Partes do referido Pacto reconhecem o direito de toda pessoa a uma condição de vida apropriada para si e sua família, assim como a uma progressão continua de sua qualidade de vida. Para tanto, os Estados Partes deverão assegurar a efetivação desse direito, através de medidas próprias para tal fim, reconhecendo assim, a relevância da cooperação internacional abarcada pelo livre consentimento.

Tal manifestação por força de Pacto Internacional sob o domínio das Nações Unidas faz, uma vez, assegurar por meio da cooperação internacional e dos países pactuantes, a preservação e garantia da dignidade do homem e sadia qualidade de vida, por meio da intangibilidade dos direitos fundamentais, preservando os direitos conquistados e persistindo na sua progressão, criando assim, meios impeditivos do retrocesso nos direitos assegurados por tão importante Pacto de Direitos Internacionais.

12 ORGANIZAÇÃO DAS NAÇÕES UNIDAS (ONU). Pacto Internacional sobre os Direitos Econômicos, Sociais e Culturais das Nações Unidas. Disponível em: <http://www.dhnet.org.br/direitos/sip/onu/doc/pacto1.htm>. Acesso em 19 maio.2014.

13 ORGANIZAÇÃO DAS NAÇÕES UNIDAS (ONU). Pacto Internacional sobre os Direitos Econômicos, Sociais e Culturais das Nações Unidas. Disponível em: <http://www.dhnet.org.br/direitos/sip/onu/doc/pacto1.htm>. Acesso em 19 maio.2014. 
QUINTERO, Jaqueline Moretti. A possibilidade do princípio da não regressão no Direito Ambiental Brasileiro. Revista Eletrônica Direito e Política, Programa de Pós-Graduação Stricto Sensu em Ciência Jurídica da UNIVALI, Itajaí, v.10, n.1, edição especial de 2015. Disponível em: www.univali.br/direitoepolitica - ISSN 1980-7791.

Essa preservação dos direitos impetrados e de amplo alcance relacionados aos direitos fundamentais também se encontra acolhida na Convenção Americana de Direitos Humanos - Pacto de São José da Costa Rica ${ }^{14}$, mais especificamente em suas Normas de Impetração, que prevê:

Artigo 29 - Normas de interpretação:

Nenhuma disposição da presente Convenção pode ser interpretada no sentido de:

a) permitir a qualquer dos Estados-partes, grupo ou indivíduo, suprimir o gozo e o exercício dos direitos e liberdades reconhecidos na Convenção ou limitá-los em maior medida do que a nela prevista;

Esta negativa para supressão de direitos já reconhecidos pela convenção vem, também, de encontro com a progressão legislativa para consecução de atos que estejam concernentes com a preservação dos direitos e liberdades individuais já garantidas em outras convenções internacionais. A prioridade de tais convenções é respeitar os direitos essenciais ao homem e a justiça social, reconhecendo ainda em seu preâmbulo a referida Convenção, que tais direitos ditos essenciais da pessoa humana não dependem do fato da nacionalidade de determinado cidadão, mas sim de estar embasado e fundamentar-se nas características da pessoa humana para atribuição desses direitos essenciais ao homem, motivo pelo qual se justifica uma proteção internacional.

Reforça ainda a preservação de tais direitos fundamentais ao homem, o Pacto de São José da Costa Rica em seu Artigo 30 ${ }^{15}$ :

Alcance das restrições: As restrições permitidas, de acordo com esta Convenção, ao gozo e exercício dos direitos e liberdades nela reconhecidos, não podem ser aplicadas

${ }^{14}$ CONVENÇÃO Americana sobre Direitos Humanos. Protocolo adicional à convenção americana sobre direitos humanos em matéria de direitos econômicos, sociais e culturais. Protocolo de São Salvador. Disponível em: $<$ http://www.cidh.oas.org/basicos/portugues/e.Protocolo_de_San_Salvador.htm >. Acesso em 14.06.2014.

${ }^{15}$ CONVENÇÃO Americana sobre Direitos Humanos. Protocolo adicional à convenção americana sobre direitos humanos em matéria de direitos econômicos, sociais e culturais. Protocolo de São Salvador. Disponível em: <http://www.cidh.oas.org/basicos/portugues/e.Protocolo_de_San_Salvador.htm >. Acesso em 14.06.2014 
QUINTERO, Jaqueline Moretti. A possibilidade do princípio da não regressão no Direito Ambiental Brasileiro. Revista Eletrônica Direito e Política, Programa de Pós-Graduação Stricto Sensu em Ciência Jurídica da UNIVALI, Itajaí, v.10, n.1, edição especial de 2015. Disponível em: www.univali.br/direitoepolitica - ISSN 1980-7791.

senão de acordo com leis que forem promulgadas por motivo de interesse geral e com o propósito para o qual houverem sido estabelecidas.

Mais pontualmente, apresenta o Documento Preliminar sobre as Normas para a Elaboração dos Relatórios Periódicos Previstos no Artigo 19 do Protocolo de San Salvador - Comissão Interamericana de Direitos Humanos ${ }^{16}$, que o escopo principal da iniciativa de desenvolvimento de relatórios periódicos a respeito das medidas progressivas que os Estados tenham adotado para afiançar o devido respeito aos direitos consagrados no mesmo Protocolo, é a criação e ordenação de diretrizes e critérios para a elaboração de tais relatórios previstos no artigo 19 do Protocolo de San Salvador, de acordo com o sistema de apontadores de progresso. Levou-se em conta, sobretudo, o princípio de progressividade dos direitos econômicos, sociais e culturais (DESC), percebendo assim, a necessidade de utilização de políticas públicas que considerem os direitos econômicos, sociais e culturais como direitos humanos cuja completude, não pode acontecer de maneira veloz, motivo pelo qual se deve entender de que se trata de processo em que cada país evolui ao seu tempo, pelos motivos básicos de recursos, infraestrutura e disponibilidade de pessoal e material, para atingir a meta por si programada. O princípio da progressão invalida qualquer medida regressiva, salvo casos extremos e plenamente justificáveis.

O Protocolo de San Salvador foi desenvolvido, objetivando a inclusão social, promovendo a acessibilidade aos direitos econômicos, sociais e culturais de forma igualitária para todos, na busca do bem comum e da progressão de direitos e garantias essenciais ao homem, sua sadia qualidade de vida e sua proteção, promovendo a ordem pública e o bem-estar de forma semelhante a todos.

Compromete-se, ainda, o Protocolo de São Salvador em seu Artigo 1, com a

16 COMISSÃO INTERAMERICANA DE DIREITOS HUMANOS. Documento preliminar sobre as normas para a elaboração dos relatórios periódicos previstos no artigo 19 do protocolo de San Salvador. 2004.2 Disponível <http://scm.oas.org/doc_public/PORTUGUESE/HIST_04/CP13722P07.DOC>. Acesso em: 07 jun.2014. 
QUINTERO, Jaqueline Moretti. A possibilidade do princípio da não regressão no Direito Ambiental Brasileiro. Revista Eletrônica Direito e Política, Programa de Pós-Graduação Stricto Sensu em Ciência Jurídica da UNIVALI, Itajaí, v.10, n.1, edição especial de 2015. Disponível em: www.univali.br/direitoepolitica - ISSN 1980-7791.

adoção de medidas internas dos Estados partes e as previstas ${ }^{17}$ :

Obrigação de adotar medidas: Os Estados Partes neste Protocolo Adicional à Convenção Americana sobre Direitos Humanos comprometem-se a adotar as medidas necessárias, tanto de ordem interna como por meio da cooperação entre os Estados, especialmente econômica e técnica, até o máximo dos recursos disponíveis e levando em conta seu grau de desenvolvimento, a fim de conseguir, progressivamente e de acordo com a legislação interna, a plena efetividade dos direitos reconhecidos neste Protocolo.

Registra, novamente, o referido Protocolo, a importância do comprometimento dos países pactuantes a cooperarem mutuamente para que as medidas de preservação dos direitos e garantias fundamentais ao homem sejam utilizadas efetivamente e que haja a progressão necessária de tais direitos, impedindo, seja nas normas internas ou nas Convenções Internacionais, qualquer óbice que possa obstruir o que foi estabelecido nesse Protocolo.

Entende assim, como direito a um meio ambiente sadio o Protocolo de São Salvador ${ }^{18}$ em seu Artigo 11:

Artigo 11 - Direito a um meio ambiente sadio: 1. Toda pessoa tem direito a viver em meio ambiente sadio e a contar com os serviços públicos básicos; 2. Os Estados Partes promoverão a proteção, preservação e melhoramento do meio ambiente.

Enaltece ainda Michel Prieur ${ }^{19}$ que diversos documentos internacionais sobre direitos humanos corroboram com a característica progressiva dos direitos econômicos, sociais e culturais, que estão habitualmente conectados como

17 CONVENÇÃO Americana sobre Direitos Humanos. Protocolo adicional à convenção americana sobre direitos humanos em matéria de direitos econômicos, sociais e culturais. Protocolo de São Salvador. Disponível em: <http://www.cidh.oas.org/basicos/portugues/e.Protocolo_de_San_Salvador.htm>. Acesso em 14.06.2014.

${ }^{18}$ CONVENÇÃO Americana sobre Direitos Humanos. Protocolo adicional à convenção americana sobre direitos humanos em matéria de direitos econômicos, sociais e culturais. Protocolo de São Salvador. $\quad$ Disponível em: <http://www.cidh.oas.org/basicos/portugues/e.Protocolo_de_San_Salvador.htm>. Acesso em 14.06.2014.

19 PRIEUR, Michel. O Princípio da "Não Regressão" no Coração do Direito do Homem e do Meio Ambiente. In: Revista Novos Estudos Jurídicos, vol. 17, n. 1, p. 06-17/jan-abr. 2012. Disponível em: <www.univali.br/nej>. Acesso em: 23 ago, 2013. p. 8. 
QUINTERO, Jaqueline Moretti. A possibilidade do princípio da não regressão no Direito Ambiental Brasileiro. Revista Eletrônica Direito e Política, Programa de Pós-Graduação Stricto Sensu em Ciência Jurídica da UNIVALI, Itajaí, v.10, n.1, edição especial de 2015. Disponível em: www.univali.br/direitoepolitica - ISSN 1980-7791.

direito ambiental. Entende-se, por força desta progressividade, uma obrigação de não regressão ou não retrocesso.

Michel Prieur ${ }^{20}$ entende ainda que o escopo principal do Direito Ambiental é o de colaborar com a redução da poluição e à conservação da diversidade biológica. Ainda assim, o Direito Ambiental encontra-se numa fase em que está aclamado em diversas constituições como um novo direito humano, encontra-se, em contrapartida, ameaçado em sua essência. Assim sendo, pergunta o autor, se não deveria o "Direito Ambiental entrar na categoria das regras jurídicas eternas, irreversíveis e, assim, não revogáveis, em nome do interesse comum da Humanidade? ${ }^{21 "}$.

E o próprio autor ${ }^{22}$ responde inteirando que diante das intimidações de regressão, principalmente no que tange ao direito ambiental, os juristas desse ramo do direito devem responder duramente, com fundamento em argumentos jurídicos que não poderão ser questionados nem pelos operadores jurídicos e nem pela opinião pública, que uma vez alertada, não aceitaria retrocessos no que concerne à proteção do meio ambiente, observando que isso implicaria ameaça à própria saúde humana.

Diante de tais ordenamentos aclamados por diversos países, prevendo a importância da manutenção da integridade dos direitos fundamentais ao homem e, podendo considerar o direito ambiental também como direito fundamental, a preservação desse ambiente para garantir o bem-estar e a dignidade que o homem requer, torna-se imprescindível no alcance das legislações internas de diversas nações assim como nas convenções e tratados internacionais, tornandose assim imperativa a preservação do meio ambiente como consagração dos direitos fundamentais ao homem.

20 PRIEUR, Michel. Princípio da proibição de retrocesso ambiental. In: Comissão de meio ambiente, defesa do consumidor e fiscalização e controle. Princípio da proibição de retrocesso ambiental. Brasília: Senado Federal, 2012. p. 12.

21 PRIEUR, Michel. Princípio da proibição de retrocesso ambiental. In: Comissão de meio ambiente, defesa do consumidor e fiscalização e controle. Princípio da proibição de retrocesso ambiental. p. 12.

22 PRIEUR, Michel. Princípio da proibição de retrocesso ambiental. In: Comissão de meio ambiente, defesa do consumidor e fiscalização e controle. Princípio da proibição de retrocesso ambiental. p. 13. 
QUINTERO, Jaqueline Moretti. A possibilidade do princípio da não regressão no Direito Ambiental Brasileiro. Revista Eletrônica Direito e Política, Programa de Pós-Graduação Stricto Sensu em Ciência Jurídica da UNIVALI, Itajaí, v.10, n.1, edição especial de 2015. Disponível em: www.univali.br/direitoepolitica - ISSN 1980-7791.

Tem-se, assim, a clareza da percepção de tão relevante admissão de fatos para o ordenamento jurídico, principalmente, para aqueles de consequências internacionais, com sanções severas e agências engajadas com a forte vigilância na preservação do meio ambiente para garantir a sadia qualidade de vida para as atuais e futuras gerações, permitindo assim, a progressão dos direitos sociais já alcançados.

\section{O PRINCÍPIO dA NÃO REgRESSÃo dO DIREITO AMBIENTAL NO DIREITO INTERNACIONAL}

Prevalecendo o entendimento de que o bem público é de uso comum, deve-se considerar para tal a importância de sua conservação e preservação pela parte de todos e para todos, ampliando para uma perspectividade de vivência comunitária com responsabilidade ambiental.

Para Rafael González Ballar ${ }^{23}$, apesar da preocupação com a necessidade do desenvolvimento sustentável e a existência de agências e órgãos mundiais vinculadas às Nações Unidas (como o PNUMA, por exemplo) para tratar desse tema, existe uma grande pressão de governos e interesses coorporativos que são contra a criação de tratados e leis ambientais por temeres que essas normativas venham a significar um atraso aos avanços econômicos. Ainda assim, é importante esclarecer que mesmo com os impedimentos econômicos que possam surgir para a criação e fortalecimento de leis de proteção ambiental, que a não regressão pode ser vista como "um dos novos conceitos jurídicos derivados do desenvolvimento de uma ética ambiental ${ }^{24}$."

O Constitucionalismo Ambiental que se aspira para este novo milênio como categoria de reconhecimento global visa estabelecer normas de aspectos de tal

23 BALLAR, Rafael González. Reflexiones para la Interpretación de la no regresión. In: PEÑA, Chacón Mario (Org.). El Princípio de no Regresión Ambiental em el Derecho Comparado Latinoamericano. São José/Costa Rica: PNUD, 2013. p. 78.

24 BALLAR, Rafael González. Reflexiones para la Interpretación de la no regresión. In: PEÑA, Chacón Mario (Org.). El Princípio de no Regresión Ambiental em el Derecho Comparado Latinoamericano. p. 80. 
QUINTERO, Jaqueline Moretti. A possibilidade do princípio da não regressão no Direito Ambiental Brasileiro. Revista Eletrônica Direito e Política, Programa de Pós-Graduação Stricto Sensu em Ciência Jurídica da UNIVALI, Itajaí, v.10, n.1, edição especial de 2015. Disponível em: www.univali.br/direitoepolitica - ISSN 1980-7791.

forma determinantes e duradouros para que possam estabelecer regras de vigor constitucional, portanto, inibindo questionamentos mais precários sobre os subsídios jurídicos a serem utilizados em suas vertentes, com o intuito de zelar pelo meio ambiente protegido nos dias atuais e para a conservação desse mesmo ambiente para o futuro que está por vir. Como assinala Tiago Fensterseifer ${ }^{25}$ a Constituição deve ser considerada um texto "vivo", edificado e renovado constantemente, considerando a herança histórica e patrimônios culturais que Ihe são acrescentados a cada fato novo, para que não se torne uma letra morta e sem efetividade jurídica.

Como bem instrui Ney de Barros Bello Filho $^{26}$ sobre o direito ao meio ambiente e seu caráter fundamental:

Por ser um direito emancipatório, que visa proteger a sociedade civil da era do risco na transição paradigmática, o direito ao ambiente sadio e ecologicamente equilibrado tem necessariamente caráter difuso e fundamental.

A aceitação do direito ambiental como direito fundamental ao homem passa, necessariamente, pelo viés de uma progressão do entendimento da importância da defesa do meio ambiente para uma expansão global do bem estar do homem e a preservação de sua espécie.

Para Canotilho ${ }^{27}$ surge a pergunta se os interesses estão juridicamente protegidos de forma que o postulador possa atingir sua satisfação quando usa de recursos por via judicial. O autor entende que só excepcionalmente deveria haver ações populares de interesses ou de associações ambientalistas, pois o sistema jurídico estaria alicerçado em uma posição jurídico-material, adotando esquemas

\footnotetext{
${ }^{25}$ FENSTERSEIFER, Tiago. Direitos Fundamentais e Proteção do Meio Ambiente: a dimensão ecológica da dignidade humana no marco jurídico-constitucional do Estado Socioambiental de Direito. p. 67.

26 BELLO FILHO, Ney de Barros. Teoria do Direito e Ecologia: apontamentos para um direito ambiental no século XXI. In: FERREIRA, Heline Sivini; MOREATO LEITE, José Rubens (Org.). Estado de Direito Ambiental: tendências: aspectos constitucionais e diagnósticos. Rio de Janeiro: Forense Universitária: 2004. p. 76.

27 CANOTILHO, José Joaquim Gomes. Estado Constitucional Ecológico e Democracia Sustentada. In: FERREIRA, Heline Sivini; MOREATO LEITE, José Rubens (Org.). Estado de Direito Ambiental: tendências: aspectos constitucionais e diagnósticos. Rio de Janeiro: Forense Universitária: 2004. p. 7.
} 
QUINTERO, Jaqueline Moretti. A possibilidade do princípio da não regressão no Direito Ambiental Brasileiro. Revista Eletrônica Direito e Política, Programa de Pós-Graduação Stricto Sensu em Ciência Jurídica da UNIVALI, Itajaí, v.10, n.1, edição especial de 2015. Disponível em: www.univali.br/direitoepolitica - ISSN 1980-7791.

processuais individualistas.

De certo modo, pode-se entender que seja necessária uma evolução para um sistema jurídico, baseado em decisões que possam privilegiar os interesses das ações públicas de forma mais ampla, conseguindo atingir o maior número de beneficiados possíveis, sem ocupar diretamente com as ações de interesse ambiental privado que tendem a privilegiar a propriedade e os bens particulares.

Na percepção de Ney de Barros Bello Filho ${ }^{28}$ a ciência levou a humanidade para o risco e tal risco é fundado diretamente na tomada de decisão, podendo gerar desastres e danos irreparáveis. De tal modo que, na sociedade de risco, a função do direito é servir como meio de participação popular nessas tomadas de decisões que poderão gerar determinados riscos a sociedade.

Para restringir tais riscos e consequências que poderão ser consideradas verdadeiros retrocessos na evolução jurídica no direito ambiental, algumas Constituições já preveem, de forma modesta ou mais ampla e especificamente a restrição aos usos de recursos naturais, a melhor maneira de preservar ecossistemas e sanções que atingem não somente de forma direta o causador ou réu da ação, mas também, a melhor maneira de reparação ao dano causado ao meio ambiente e aqueles diretamente afetados por esse dano.

Mesmo sendo difícil mensurar, em alguns casos, a amplitude do impacto ambiental causado negativamente à natureza e ao ser humano, as normas ambientais, atualmente, evoluem para cerrar mais forte e concretamente o alcance e poder de ação de tais normas, utilizando categoricamente os princípios da prevenção e da precaução, tentando impedir assim que transgressões ainda maiores possam ocorrer.

Algumas constituições da América do Sul merecem destaque em tal evolução jurídica especificamente voltada ao Direito Ambiental, como as dos Países Equador e Bolívia, que tem inserido no próprio texto de sua Carta Magna, títulos

28 BELLO FILHO, Ney de Barros. Teoria do Direito e Ecologia: apontamentos para um direito ambiental no século XXI. In: FERREIRA, Heline Sivini; MOREATO LEITE, José Rubens (Org.). Estado de Direito Ambiental: tendências: aspectos constitucionais e diagnósticos. Rio de Janeiro: Forense Universitária: 2004. p. 88 e 91. 
QUINTERO, Jaqueline Moretti. A possibilidade do princípio da não regressão no Direito Ambiental Brasileiro. Revista Eletrônica Direito e Política, Programa de Pós-Graduação Stricto Sensu em Ciência Jurídica da UNIVALI, Itajaí, v.10, n.1, edição especial de 2015. Disponível em: www.univali.br/direitoepolitica - ISSN 1980-7791.

inteiros tratando da preocupação com a preservação do meio ambiente e na precaução do impacto ambiental e da degração desse meio.

Na Constituição da Bolívia ${ }^{29}$, que preconiza que o Estado deverá administrar os recursos naturais em função do interesse público, possui uma Seção especial em seu Capítulo Quinto dedicada ao Meio Ambiente. Na referida Seção, a Constituição Boliviana já em seu Artigo 33 determina:

As pessoas têm direito a um meio ambiente saudável, protegido e equilibrado. $O$ exercício deste direito deve permitir aos indivíduos e às coletividades das presentes e futuras gerações, além de outros seres vivos, se desenvolver de maneira normal e permanente.

Além deste relevante artigo, que já enaltece a importância da garantia ao meio ambiente saudável para as atuais e futuras gerações, prevê também em seus artigos 34 e $138^{30}$ garante também o direito à representação individual ou coletiva para exercer os direitos de defender este direito de defender os possíveis atentados ao meio ambiente, garantindo assim o acesso à justiça através de ações públicas, que possam segurar ao cidadão a observância dos prejuízos ao ambiente natural e a permanência de sua conservação, obtendo ainda o respaldo da administração pública, que pode e deve fazer de ofício sua própria representação pública, contra as possíveis ameaças que possam ir contra os direitos estabelecidos nessa Constituição.

Possui ainda referida Constituição, Tribunal específico estabelecido em seu Artigo $198^{31}$ denominado Tribunal Agroambiental, que deve resolver os recursos de cassação e nulidade de ações relacionadas aos temas agrários, florestais,

${ }^{29}$ BOLÍVIA. Constitución politica del Estado. Magna Asamblea Constituyente, 2007. Disponível em: <http://www.transparencialegislativa.org/wp-content/uploads/2013/04/Constitucio\%CC\%81nBolivia.pdf> Acessado em: 12.04.2014. Texto original: Las personas tienen derecho a un medio ambiente saludable, protegido y equilibrado. El ejercicio de este derecho debe permitir a los individuos y colectividades de las presentes y futuras generaciones, además de otros seres vivos, desarrollarse de manera normal y permanente. Livre tradução da autora.

${ }^{30}$ BOLÍVIA. Constitución politica del Estado. Magna Asamblea Constituyente, 2007. Disponível em: <http://www.transparencialegislativa.org/wp-content/uploads/2013/04/Constitucio\%CC\%81nBolivia.pdf> Acessado em: 12.04.2014.

${ }^{31}$ BOLÍVIA. Constitución politica del Estado. Magna Asamblea Constituyente, 2007. Disponível em: <http://www.transparencialegislativa.org/wp-content/uploads/2013/04/Constitucio\%CC\%81nBolivia.pdf> Acessado em: 12.04.2014. 
QUINTERO, Jaqueline Moretti. A possibilidade do princípio da não regressão no Direito Ambiental Brasileiro. Revista Eletrônica Direito e Política, Programa de Pós-Graduação Stricto Sensu em Ciência Jurídica da UNIVALI, Itajaí, v.10, n.1, edição especial de 2015. Disponível em: www.univali.br/direitoepolitica - ISSN 1980-7791.

ambientais, de águas, direito de utilização dos recursos naturais renováveis, hídricos, da biodiversidade e ações relacionadas à fauna, flora, e meio ambiente, além das que possam colar em situação de perigo o sistema ecológico e a conservação de espécies e de animais. Dá ainda o poder para resoluções em instância única de processos administrativos relacionados a contratos, autorizações e outorga relativos ao direito de aproveitamento dos recursos naturais renováveis.

Ainda traz em seu Título II a Constituição Boliviana, um espaço cedido exclusivamente ao meio ambiente, recursos naturais, à terra e ao território, destacando o dever do Estado e de sua população para o uso sustentável dos recursos naturais e da biodiversidade, assim como sua conservação e preservação, ressaltando em seu Artigo $341^{32}$ o direito à população de participar efetivamente da gestão ambiental, participando de consulta prévia e devidamente informativa sobre decisões que possam afetar a qualidade do meio ambiente. Este artigo traz um estágio evolutivo jurídico que permite a prevenção com a participação pública, permitindo uma verdadeira governança ambiental, autorizando juridicamente a participação popular na tomada de decisões sobre o desenvolvimento sustentável, de tal maneira que a prevenção e a precaução para as atividades que atinjam diretamente o meio ambiente estejam à frente das decisões políticas e econômicas tomadas exclusivamente pelo Estado. Esta importante inserção permite trabalhar de forma democrática as ações governamentais que afetam e afetarão diretamente a sadia qualidade ambiental para os cidadãos mais engajados e que tenham participação efetiva nas organizações políticas representativas, como também para aqueles que estão sendo representados em argumentações que aferirão ações preocupadas com a preservação ambiental para todos.

Ainda na América do Sul, apresenta-se com semelhante qualidade quanto aos quesitos de previsão jurídica para a preservação e conservação ambiental a

${ }^{32}$ BOLÍVIA. Constitución politica del Estado. Magna Asamblea Constituyente, 2007. Disponível em: <http://www.transparencialegislativa.org/wp-content/uploads/2013/04/Constitucio\%CC\%81nBolivia.pdf> Acessado em: 12.04.2014. 
QUINTERO, Jaqueline Moretti. A possibilidade do princípio da não regressão no Direito Ambiental Brasileiro. Revista Eletrônica Direito e Política, Programa de Pós-Graduação Stricto Sensu em Ciência Jurídica da UNIVALI, Itajaí, v.10, n.1, edição especial de 2015. Disponível em: www.univali.br/direitoepolitica - ISSN 1980-7791.

Constituição do Equador ${ }^{33}$, que possui uma Seção especial tratando da natureza e do meio ambiente a partir de seu Artigo 395, além de seções específicas que tratam de normas jurídicas relacionadas à biodiversidade, o patrimônio natural e ecossistemas, recursos naturais, à conservação do solo, água, Biosfera, ecologia urbana e energias alternativas.

A referida constituição em seu Artigo 410, envolvendo inteligentemente a atuação da população na preocupação da conservação do ambiente, estabelece o apoio às comunidades rurais para a conservação e restauração do solo, como também o desenvolvimento de práticas agrícolas que protejam e promovam a autonomia alimentar. Este artigo demonstra que o Estado está claramente assumindo sua incapacidade em gerir a preservação do meio ambiente no espaço rural, especificamente preocupado com a preservação do solo, tema de destaque em conferências sobre a preservação do planeta em vários países, estimulando a participação do agricultor que trata diretamente com a conservação do solo e dele retém não somente seu alimento, mas, o fornecimento de sua economia familiar, para que auxilie diretamente neste trabalho de tratamento para a preservação do solo como preservação do meio ambiente para todos.

É necessário utilizar, através inclusive de normas jurídicas, alternativas e previsões que permitam uma maior atuação por parte da população, para que possa ser percebida pelo cidadão a importância de suas ações na conservação do meio ambiente, assim como garantir uma governança ambiental efetiva através dos instrumentos da administração pública permitidos pelo que está previsto na legislação vigente.

A Constituição Equatoriana estabelece ainda, seu Artigo $395^{34}$, importante marco para o estabelecimento de regras determinísticas no que envolve o meio

33 EQUADOR. Constitución de la República del Ecuador. Asamblea Constituyente, 2008. Disponível

em: <http://www.stf.jus.br/repositorio/cms/portalStfInternacional/newsletterPortalInternacionalFoco/an exo/ConstituicaodoEquador.pdf $>$ Acessado em 11.04.2014.

34 EQUADOR. Constitución de la República del Ecuador. Asamblea Constituyente, 2008. Disponível em: <http://www.stf.jus.br/repositorio/cms/portalStfInternacional/newsletterPortalInternacionalFoco/an exo/ConstituicaodoEquador.pdf> Acessado em 11.04.2014. 
QUINTERO, Jaqueline Moretti. A possibilidade do princípio da não regressão no Direito Ambiental Brasileiro. Revista Eletrônica Direito e Política, Programa de Pós-Graduação Stricto Sensu em Ciência Jurídica da UNIVALI, Itajaí, v.10, n.1, edição especial de 2015. Disponível em: www.univali.br/direitoepolitica - ISSN 1980-7791.

ambiente, instituindo como Princípio Ambiental para o caso de dúvidas sobre o alcance das disposições legais em matéria ambiental, será aplicada a legislação mais favorável à proteção da natureza.

Semelhante destaque estabelece a Constituição Política da República do Chile ${ }^{35}$, em seu artigo $8^{\circ}$, quando determina que a lei poderá estabelecer restrições específicas ao exercício de determinados direitos ou liberdades, para proteger o meio ambiente, enfatiza ainda que é dever do Estado velar para o direito a um meio ambiente livre de contaminação e tutelar a preservação da natureza.

Diante de regras tão claramente estabelecidas no corpo da Constituição de países como o Chile e o Equador, estabelecendo a importância da preservação do meio ambiente, para garantir a conservação desse ambiente e uma sadia qualidade de vida ao cidadão, em detrimento de outras leis que se mostrarem conflituosas, demonstra, não somente, a equivalência do direito ambiental como direito fundamental, como também uma visão de procedimentos jurídicos preocupados com o futuro das civilizações daqueles países.

Parece, então, que tal reconhecimento jurídico pode ser utilizado no benefício dos direitos e garantias fundamentais ao homem, na preservação da segurança de um ambiente equilibrado e sadio, para si, sua família e os demais de sua comunidade, permitindo um direito que possa alcançar o maio número de pessoas possivelmente beneficiados por esse direito e não apenas um grupo determinado ou uma única pessoa, como deve ser o direito difuso. Como esclarece Gabriel Ferrer ${ }^{36}$, nos países menos desenvolvidos, o Direito Ambiental é um direito em desenvolvimento que tem, como vocação imediata, o ensaio de modelos sociais e econômicos com o objetivo principal de reduzir a pobreza e melhorar a qualidade de vida dos seus habitantes.

A justiça ambiental, seja em nível nacional ou transnacional, deve sempre questionar-se sobre a dimensão das causas e efeitos dos danos ambientais e de

35 CHILE. Constitucion Politica de la Republica de Chile. Asamblea Constituyente, 1980. Disponível em: <http://www.constitution.org/cons/chile.htm.> Acessado em 12.05.2014.

36 FERRER, Gabriel Real. La Construcción del Derecho Ambiental. In: Revista Novos Estudos Jurídicos, v.18, n.3, set-dez/2013, p. 260. 
QUINTERO, Jaqueline Moretti. A possibilidade do princípio da não regressão no Direito Ambiental Brasileiro. Revista Eletrônica Direito e Política, Programa de Pós-Graduação Stricto Sensu em Ciência Jurídica da UNIVALI, Itajaí, v.10, n.1, edição especial de 2015. Disponível em: www.univali.br/direitoepolitica - ISSN 1980-7791.

que maneira poderão, observando suas regras internas e os tratados e convenções internacionais (logicamente aqueles assinados por seu país) minimizar os efeitos degradantes ao meio ambiente e às comunidades atingidas, para que o agravo ambiental seja o menor possível e, no caso do dano já causado, a recuperação ocorra para a reconstrução, ainda que lenta, da área a ser restituída. Como enfatiza Ney de Barros Bello Filho 37 : "[...], o direito somente enfrenta a era do risco preservando o ambiente, se se livrar das amarras clássicas regulatórias e construir caminho como espaço e instrumento de solidariedade e de emancipação popular."

Para o bom desenvolvimento da capacidade do homem e a manutenção de sua segurança como também o respeito aos seus direitos mais preciosos como a igualdade e liberdade podem ser instrumentalizados através das ações judiciárias é importante a clareza constante da lei positivada e dos princípios estabelecidos pelos regramentos utilizados no Estado, a fim de não permitir que interesses pessoais ou de pequenos grupos sobreponham-se ao interesse coletivo, permitindo a abrangência da utilização da lei para garantia de direitos difusos alcançados no decorrer histórico da evolução do homem.

\section{O PRINCÍPIO DA NÃO REgRESSÃO COMO TUTELA DO DIREITO AMBIENTAL BRASILEIRO}

A evolução do Direito Ambiental no Brasil aponta para um desenvolvimento que não deverá retroceder pela qualidade legislativa encontrada nas normas especificamente criadas para a preservação do ambiente. Abrindo as perspectivas de amadurecimento para com a preocupação da conservação ambiental, a Constituição da República Federativa do Brasil de 1988 no reconhecimento em seu art. 225 do direito ao meio ambiente ecologicamente equilibrado, tratando exclusivamente em seu capítulo VI da obrigatoriedade ao Poder Público e à coletividade o dever de defendê-lo e preservá-lo para as

37 BELLO FILHO, Ney de Barros. Teoria do Direito e Ecologia: apontamentos para um direito ambiental no século XXI. In: FERREIRA, Heline Sivini; MORATO LEITE, José Rubens (Org.). Estado de Direito Ambiental: tendências: aspectos constitucionais e diagnósticos. p. 95. 
QUINTERO, Jaqueline Moretti. A possibilidade do princípio da não regressão no Direito Ambiental Brasileiro. Revista Eletrônica Direito e Política, Programa de Pós-Graduação Stricto Sensu em Ciência Jurídica da UNIVALI, Itajaí, v.10, n.1, edição especial de 2015. Disponível em: www.univali.br/direitoepolitica - ISSN 1980-7791.

presentes e futuras gerações.

Ainda na referida Constituição, em seu Título II, que trata dos direitos e garantias fundamentais, mais especificamente em seu artigo 50, LXXIII ${ }^{38}$, institui que:

[...] qualquer cidadão é parte legítima para propor ação popular que vise a anular ato lesivo ao patrimônio público ou de entidade de que o Estado participe, à moralidade administrativa, ao meio ambiente e ao patrimônio histórico e cultural, ficando o autor, salvo comprovada má-fé, isento de custas judiciais e do ônus da sucumbência;

Além de estabelecer em seus artigos 22 e 23 estabelece ao Estado a responsabilidade de proteger o meio ambiente e combater a poluição em qualquer de suas formas e legislar sobre tal proteção, trata ainda, no que tange à ordem econômica, especificamente em seu ar Artigo $170, \mathrm{VI}^{39}$, que tem como fim assegurar a todos existência digna, conforme os ditames da justiça social, observando o princípio da defesa do meio ambiente, inclusive mediante tratamento diferenciado conforme o impacto ambiental dos produtos e serviços e de seus processos de elaboração e prestação. Apresenta também a preocupação com a função social da propriedade em seu artigo 186, II.

O Brasil possui ainda uma gama de normativas infraconstitucionais para tratar especificamente da preservação ambiental como a Lei da Política Nacional do Meio Ambiente (Lei n. ${ }^{\circ} 6.938$ de 17 de janeiro de 1981), criando a obrigatoriedade de indenização para o poluidor aos danos ambientais causados, instituindo ainda a obrigatoriedade dos estudos e relatórios sobre o Impacto Ambiental (EIA/RIMA) para o licenciamento de atividades que possam causar modificações ao meio ambiente. Esta Lei que deu início à composição da legislação ambiental brasileira possui uma série de instrumentos e critérios para o planejamento, a gestão ambiental e a fiscalização, permitindo ao poder público uma fiscalização mais abrangente com regras mais claras sobre as áreas

\footnotetext{
38 BRASIL. Constituição da República Federativa do Brasil. Disponível em: <http://www.planalto.gov.br/ccivil_03/constituicao/constituicao.htm>. Acesso em 29 ago.13.

39 BRASIL. Constituição da República Federativa do Brasil. Disponível em: <http://www.planalto.gov.br/ccivil_03/constituicao/constituicao.htm>. Acesso em 29 ago.13.
} 
QUINTERO, Jaqueline Moretti. A possibilidade do princípio da não regressão no Direito Ambiental Brasileiro. Revista Eletrônica Direito e Política, Programa de Pós-Graduação Stricto Sensu em Ciência Jurídica da UNIVALI, Itajaí, v.10, n.1, edição especial de 2015. Disponível em: www.univali.br/direitoepolitica - ISSN 1980-7791.

prioritárias para preservação.

No mesmo ano da Constituição vigente no Brasil, foi criada ainda a Lei do Gerenciamento Costeiro (Lei n.o 7.661 de 16 de maio de 1988), que define as orientações para criar o Plano Nacional de Gerenciamento Costeiro, permitindo aos próprios estados e municípios criarem seus planos de gerenciamento costeiro, prevalecendo as normas de restrição da preservação dos recursos naturais da faixa marítima e terrestres abrangidos pela zona costeira.

Já em 1997, foi instituída a Lei de Recursos Hídricos (Lei no 9.433 de 08 de janeiro de 1997) estabelecendo que a água é um recurso natural limitado, possuidor de valor econômico, com várias possibilidades de utilização, criando ainda o Sistema Nacional de Informação sobre Recursos Hídricos para a coleta, tratamento, armazenagem e recuperação de informações sobre recursos hídricos e fatores que possam interferir em sua gestão.

O que prejudica a efetividade da aplicação da lei é a escassez de recursos e de pessoal técnico especializado em número suficiente para atingir todas as regiões e microrregiões brasileiras. A aprovação de Lei de Crimes Ambientais (Lei 9.605, de 12/02/1998) é prova da evolução da legislação brasileira e de que forma, o legislativo brasileiro está buscando alternativas através das sanções penais e administrativas para impedir, prevenir e, em alguns casos, até reverter a degração penal, responsabilizando tanto pessoa física quanto pessoa jurídica pelo ato praticado.

O Novo Código Florestal (Lei no 12.651, de 25 de maio de 2012), determina que aqueles que tiverem áreas de preservação permanente (APP) e/ou reserva legal abaixo dos mínimos obrigatórios devem aderir aos Programas de Regularização Ambiental (PRA). O novo Código avalia com maior rigor as mudanças em termos de obrigações ambientais e de direitos concedidos aos proprietários de terras, com a pretensão de reduzir o desmatamento e trazer benefícios ambientais, devendo continuar com o investimento fiscalização e vigilância.

A legislação ambiental brasileira está sendo considerada uma das legislações ambientais mais completas da atualidade em nível mundial. Tal desempenho 
QUINTERO, Jaqueline Moretti. A possibilidade do princípio da não regressão no Direito Ambiental Brasileiro. Revista Eletrônica Direito e Política, Programa de Pós-Graduação Stricto Sensu em Ciência Jurídica da UNIVALI, Itajaí, v.10, n.1, edição especial de 2015. Disponível em: www.univali.br/direitoepolitica - ISSN 1980-7791.

evolutivo legislativo do Brasil nas questões relacionadas ao meio ambiente permite perceber que existe uma progressão nos estabelecimento de normas jurídicas de preservação do meio ambiente brasileiro, para que as ações de preservação e precaução possam ser inibidores de atividades danosas ao ambiente, criando um forte embasamento jurídico impeditivo ao seu retrocesso legal.

Como esclarece Chacón Mario Peña ${ }^{40}$, o Princípio de Não Regressão estabelece que a norma ou jurisprudência ambiental não deve ser revisto se houver a possibilidade de retrocesso nas questões relacionadas à proteção já alcançados em seu histórico de evolução jurídica. A sua principal finalidade é o impedimento de supressão da norma ou a redução de suas exigências em função de interesses contrários ao interesse público ambiental, já que foi possível constatar em algumas situações, que tal retrocesso legal torna permissiva a consequência de danos ambientais irreversíveis ou de difícil reparação, o que a própria jurisdição ambiental mundial no âmbito de sua evolução entende como inadmissível.

Mais além do positivismo jurídico, há que se utilizar as ferramentas jurídicas embasadas nesse positivismo, mas com um entendimento de que possa atingir níveis mais abrangentes e eficazes, como decisões judiciais que tenham a eficácia espera da lei afetando diretamente não somente as partes envolvidos no processo, mas também, aqueles que poderão ter sofrido algum dano, ou como forma de prevenir que o dano venha ocorrer, demonstrando assim a sua capacidade de amparo legal ao coletivo e não somente às partes envolvidas na lide.

Como bem caracteriza Zenildo Bodnar ${ }^{41}$, identifica-se atualmente a grave crise do positivismo pela falta de legitimidade e pela sua ineficácia, permitindo o surgimento assim do pluralismo como um dos modos racionais considerados apropriados para que a magistratura do novo milênio possa atender com maior

40 PEÑA, Chacón Mario. El principio de no regresión ambiental en la legislación y jurisprudência Costarricense. In: PEÑA, Chacón Mario (Org.). El Princípio de no Regresión Ambiental em el Derecho Comparado Latinoamericano. São José/Costa Rica: PNUD, 2013.

41 BODNAR, Zenildo. O Poder Judiciário e a Tutela do Meio Ambiente. Disponível em: <http://www.egov.ufsc.br/portal/sites/default/files/anexos/26863-26865-1-PB.pdf > Acesso em 13 jun.2014. p.9. 
QUINTERO, Jaqueline Moretti. A possibilidade do princípio da não regressão no Direito Ambiental Brasileiro. Revista Eletrônica Direito e Política, Programa de Pós-Graduação Stricto Sensu em Ciência Jurídica da UNIVALI, Itajaí, v.10, n.1, edição especial de 2015. Disponível em: www.univali.br/direitoepolitica - ISSN 1980-7791.

competência para atender aos novos litígios ambientais da sociedade moderna, esclarecendo que a função social do processo demanda ao juiz que este processo se torne mais democrático e eficaz, permitindo também que as partes participem mais ativamente do processo, abrindo a possibilidade que um maior número de pessoas interessadas possa participar da ação, como geralmente ocorrer nos processos ambientais, pois dizem respeito a toda a sociedade, podendo contribuir assim, para uma decisão mais justa.

A compreensão por parte dos Tribunais brasileiros no que condiz ao estabelecimento de claros critérios embasados na Constituição Brasileira atual é um grande e poderoso passo para que o direito ambiental brasileiro tenha subsídios consistentes para atingir, intensamente, a todas as camadas da sociedade e, principalmente nos setores que utilizam e modificam o meio ambiente para a produção e comércio de produtos, para a conscientização para o cumprimento das normas legais ambientais, para atingir a coletividade garantindo o equilíbrio para o meio ambiente e a sadia qualidade de vida do homem.

Ainda na seara jurisdicional brasileira, mais especificamente o Ministério Público de Santa Catarina, através da ADIN n. 14.661/2009, de 26 de maio de 2009 reconhece que começa a surgir no ordenamento jurídico brasileiro o princípio constitucional da proibição do retrocesso ecológico, como instrumento de defesa e amparo jurídico diante da possibilidade de supressão de direitos constitucionais adotados, porém não irrestritamente resguardados por institutos próprios, tais como o direito adquirido, o ato jurídico perfeito, a coisa julgada ou ainda o reconhecido status de cláusula pétrea. Dando continuidade, a referida Ação Direta de Inconstitucionalidade, esclarece que o principio da proibição do retrocesso ecológico significa que, a menos que as ocorrências de fato sejam alteradas de forma significativa, não servirá para a admissibilidade de retroceder para níveis de proteção abaixo dos aplicados e reconhecidos anteriormente. Assim sendo, o princípio de não regressão impõe limites à adoção de qualquer

42 BRASIL. Ministério Público de Santa Catarina. ADIN n. 14.661/2009, de 26 de maio de 2009. 
QUINTERO, Jaqueline Moretti. A possibilidade do princípio da não regressão no Direito Ambiental Brasileiro. Revista Eletrônica Direito e Política, Programa de Pós-Graduação Stricto Sensu em Ciência Jurídica da UNIVALI, Itajaí, v.10, n.1, edição especial de 2015. Disponível em: www.univali.br/direitoepolitica - ISSN 1980-7791.

espécie de legislação de revisão ou revogatória.

Conforme o entendimento de Antonio Herman Benjamin ${ }^{43}$, "[...] o maior investimento reclamado, não é, por conseguinte, em dispêndio de escassos recursos financeiros públicos, que competem com outras prioridades do Estado, mas em poupança dos recursos naturais que ainda existem."

Justificando-se, assim, a impossibilidade de barganha política sobre o Princípio do Não Retrocesso Ambiental e, já que não há, em princípio, necessidade de investimentos de recursos financeiros por parte do Estado para a continuidade de obediência legal no que diz respeito à preservação do meio ambiente.

Antonio Herman Benjamin ${ }^{44}$ salienta ainda que o progresso da humanidade, através do texto constitucional brasileiro trata do progresso "da e para a humanidade", uma "aspiração constitucionalizada de melhoria universal". Ressalta também que no controle judicial de retrocesso ambiental deve-se observar que se o dano ambiental for tomado como custo social, não passa de tributação para as gerações futuras, obrigações que não passam de imposição política aos nossos descendentes, que não participaram da degração ambiental causada nos dias atuais ${ }^{45}$.

A preocupação com as gerações futuras além da geração atual, que está, justamente, fazendo modificações para este futuro daqueles que ainda estão por vir, é fundamental para estabelecer normas que não sejam atenuantes, mas sim, de peso com caráter moralizador para servir como modelo de preservação para o meio ambiente e vida digna ao homem.

\footnotetext{
43 BENJAMIN, Antonio Herman. Princípio da Proibição de Retrocesso Ambiental In: COMISSÃO DE MEIO AMBIENTE, DEFESA DO CONSUMIDOR E FISCALIZAÇÃO E CONTROLE. Princípio da proibição de retrocesso ambiental. Brasília: Senado Federal, 2012. p. 60.

${ }^{44}$ BENJAMIN, Antonio Herman. Princípio da Proibição de Retrocesso Ambiental In: COMISSÃO DE MEIO AMBIENTE, DEFESA DO CONSUMIDOR E FISCALIZAÇÃO E CONTROLE. Princípio da proibição de retrocesso ambiental. Brasília: Senado Federal, 2012. p. 56.

45 BENJAMIN, Antonio Herman. Princípio da Proibição de Retrocesso Ambiental In: COMISSÃO DE MEIO AMBIENTE, DEFESA DO CONSUMIDOR E FISCALIZAÇÃO E CONTROLE. Princípio da proibição de retrocesso ambiental. Brasília: Senado Federal, 2012. p. 70.
} 
QUINTERO, Jaqueline Moretti. A possibilidade do princípio da não regressão no Direito Ambiental Brasileiro. Revista Eletrônica Direito e Política, Programa de Pós-Graduação Stricto Sensu em Ciência Jurídica da UNIVALI, Itajaí, v.10, n.1, edição especial de 2015. Disponível em: www.univali.br/direitoepolitica - ISSN 1980-7791.

\section{CONSIDERAÇÕES FINAIS}

Para que sejam mantidas e garantidas as leis nacionais e documentos internacionais com força e efeito jurídico, é importante esclarecer que determinadas regras, de caráter fundamental à vida do homem, devem ser preservadas por força legal para que sejam protegidas legalmente as necessidades essências ao homem e aos seus herdeiros. Entende assim a importância do princípio da não regressão Carlos Alberto Molinaro ${ }^{46}$ que está diretamente interligado aos princípios da dignidade da pessoa humana e da segurança jurídica, atribuindo-Ihe assim essencialidade para a responsabilidade ambiental informada pela fraternidade, que deve estar cunhada em todas as relações com o ambiente.

Torna-se, assim, crucial a percepção do direito ambiental como direito fundamental ao homem e, como tal, a garantia e segurança da manutenção da integridade legislativa que o preserva. Invoca-se, então, o Princípio da Não Regressão Ambiental para que tal princípio possa ser reflexo da apreensão para com a necessária qualidade de vida humana, passando pelo meio ambiente equilibrado, garantido por normas jurídicas que não possam ser retrogradadas, mas sim, observadas como já consagradas pelo direito ambiental, imputandoIhes a impossibilidade de alteração, revisão ou inversão do sentido e direitos já adquiridos para garanti dos direitos fundamentais ao homem.

Para tal desempenho, espera-se assim, poder contar com políticas públicas inovadoras na busca de alternativas que visem à preservação através do desenvolvimento sustentável, tentando realizar acordos com empresas e órgãos de representatividade coletiva, para um desenvolvimento permissivo às regras de controle ambiental, utilizando uma governança ambiental que permita um crescimento integrado e responsável com a conservação do meio ambiente.

Esta governança ambiental deve estar ocupada também com programas direcionados à educação ambiental para conscientização sobre a importância da

${ }^{46}$ MOLINARO, Carlos Alberto. Reflexões sobre um Princípio. In: COMISSÃO DE MEIO AMBIENTE, DEFESA DO CONSUMIDOR E FISCALIZAÇÃO E CONTROLE. Princípio da proibição de retrocesso ambiental. Brasília: Senado Federal, 2012. p. 78. 
QUINTERO, Jaqueline Moretti. A possibilidade do princípio da não regressão no Direito Ambiental Brasileiro. Revista Eletrônica Direito e Política, Programa de Pós-Graduação Stricto Sensu em Ciência Jurídica da UNIVALI, Itajaí, v.10, n.1, edição especial de 2015. Disponível em: www.univali.br/direitoepolitica - ISSN 1980-7791.

preservação e manutenção do meio ambiente, e que possa envolver, crianças e jovens em atividades que possam demonstrar a importância da conservação de um ambiente sadio para uma vida em qualidade em sua comunidade.

É de extrema importância que tais atividades governamentais e também vinculadas a atividades sociais estejam amparadas por leis que possam ser efetivadas através de decisões ambientais que visem à progressão do entendimento para a conservação do meio ambiente, privilegiando os interesses difusos em detrimento dos interesses de pequenos grupos.

Assim, unindo em consonância as vontades dos poderes executivo, legislativo e judiciário, para beneficiar a preservação e conservação da qualidade de vida humana e de um meio ambiente ecologicamente equilibrado, representando os interesses coletivos, poder-se-á utilizar-se de princípios que não retrocedam aos interesses alcançados pela sociedade no seu desenvolvimento histórico, permitindo-se a utilização de normas jurídicas benéficas a este bem estar social e preservação do meio ambiente.

\section{REFERÊNCIAS DAS FONTES CITADAS}

BALLAR, Rafael González. Reflexiones para la Interpretación de la no regresión. In: PEÑA, Chacón Mario (Org.). EI Princípio de no Regresión Ambiental em el Derecho Comparado Latinoamericano. São José/Costa Rica: PNUD, 2013.

BELLO FILHO, Ney de Barros. Teoria do Direito e Ecologia: apontamentos para um direito ambiental no século XXI. In: FERREIRA, Heline Sivini; MORATO LEITE, José Rubens (Org.). Estado de Direito Ambiental: tendências: aspectos constitucionais e diagnósticos. Rio de Janeiro: Forense Universitária: 2004. p. 71-108.

BENJAMIN, Antônio Herman. Constitucionalização do Ambiente e Ecologização da Constituição Brasileira. In: CANOTILHO, José Joaquim Gomes; LEITE, José Rubens Morato. (Orgs.). Direito Constitucional Ambiental Brasileiro. 3. ed. São Paulo: Saraiva, 2010.

BENJAMIN, Antonio Herman. Princípio da Proibição de Retrocesso Ambiental In: COMISSÃO DE MEIO AMBIENTE, DEFESA DO CONSUMIDOR E FISCALIZAÇÃO E CONTROLE. Princípio da proibição de retrocesso ambiental. Brasília: Senado Federal, 2012.

BODNAR, Zenildo. O Poder Judiciário e a Tutela do Meio Ambiente. Disponível em: 
QUINTERO, Jaqueline Moretti. A possibilidade do princípio da não regressão no Direito Ambiental Brasileiro. Revista Eletrônica Direito e Política, Programa de Pós-Graduação Stricto Sensu em Ciência Jurídica da UNIVALI, Itajaí, v.10, n.1, edição especial de 2015. Disponível em: www.univali.br/direitoepolitica - ISSN 1980-7791.

<http://www.egov.ufsc.br/portal/sites/default/files/anexos/26863-26865-1PB.pdf> Acesso em 13 jun.2014.

BOLÍVIA. Constitución politica del Estado. Magna Asamblea Constituyente, 2007. Disponível em: <http://www.transparencialegislativa.org/wpcontent/uploads/2013/04/Constitucio\%CC\%81n-Bolivia.pdf> Acessado em: 12.04.2014.

BRASIL. Constituição da República Federativa do Brasil. Disponível em: <http://www.planalto.gov.br/ccivil_03/constituicao/constituicao.htm>. Acesso em 29 ago.13.

BRASIL. Lei 12.651, de 25 de maio de 2012. Novo Código Florestal Brasileiro. Brasília, 2012. Disponível em: <http://www.planalto.gov.br/ccivil_03/_ato20112014/2012/lei/l12651.htm>. Acesso em 10 maio.2014.

BRASIL. Ministério Público de Santa Catarina. ADIN n. 14.661/2009, de 26 de maio de 2009. Disponível em: <http://portal.mp.sc.gov.br/portal/conteudo/cao/ceccon/adins/peticoes/2009/20 09.027858-3.pdf> Acessado em 20.06.2014.

CANOTILHO, José Joaquim Gomes. Estado Constitucional Ecológico e Democracia Sustentada. In: FERREIRA, Heline Sivini; MOREATO LEITE, José Rubens (Org.). Estado de Direito Ambiental: tendências: aspectos constitucionais e diagnósticos. Rio de Janeiro: Forense Universitária: 2004. P. 3-16.

COMISSÃO INTERAMERICANA DE DIREITOS HUMANOS. Documento preliminar sobre as normas para a elaboração dos relatórios periódicos previstos no artigo 19 do protocolo de San Salvador. 2004. Disponível em: <http://scm.oas.org/doc_public/PORTUGUESE/HIST_04/CP13722P07.DOC>. Acesso em: 07 jun.2014

CONVENÇÃO Americana sobre Direitos Humanos. Protocolo adicional à convenção americana sobre direitos humanos em matéria de direitos econômicos, sociais e culturais. Protocolo de São Salvador. Disponível em: <http://www.cidh.oas.org/basicos/portugues/e.Protocolo_de_San_Salvador.ht> . Acesso em 14.06.2014.

EQUADOR. Constitución de la República del Ecuador. Asamblea Constituyente, $2008 . \quad$ Disponível em: <http://www.stf.jus.br/repositorio/cms/portalStfInternacional/newsletterPortalInt ernacionalFoco/anexo/ConstituicaodoEquador.pdf> Acessado em 11.04.2014.

FENSTERSEIFER, Tiago. Direitos Fundamentais e Proteção do Meio Ambiente: a dimensão ecológica da dignidade humana no marco jurídicoconstitucional do Estado Socioambiental de Direito. Porto Alegre: Livraria do Advogado, 2008.

FERRER, Gabriel Real. La Construcción del Derecho Ambiental. In: Revista Novos Estudos Jurídicos, v.18, n.3, set-dez/2013, p. 260.

MOLINARO, Carlos Alberto. Direito Ambiental: proibição de retrocesso. Porto Alegre: Livraria do Advogado, 2007.

MOLINARO, Carlos Alberto. Reflexões sobre um Princípio. In: COMISSÃO DE MEIO AMBIENTE, DEFESA DO CONSUMIDOR E FISCALIZAÇÃO E CONTROLE. 
QUINTERO, Jaqueline Moretti. A possibilidade do princípio da não regressão no Direito Ambiental Brasileiro. Revista Eletrônica Direito e Política, Programa de Pós-Graduação Stricto Sensu em Ciência Jurídica da UNIVALI, Itajaí, v.10, n.1, edição especial de 2015. Disponível em: www.univali.br/direitoepolitica - ISSN 1980-7791.

Princípio da proibição de retrocesso ambiental. Brasília: Senado Federal, 2012.

NAÇÕES UNIDAS. Conferência das Nações Unidas sobre o Desenvolvimento Sustentável. El futuro que queremos. Rio de Janeiro, junho de 2012. Disponível em: <https://rio20.un.org/sites/rio20.un.org/files/a-conf.216-I1_spanish.pdf.pdf.> Acesso em 10 abr.2014.

NAÇÕES UNIDAS. Declaração Universal dos Direitos Humanos de 10 de Dezembro de 1948. Assembléia Geral das Nações Unidas em 10 de dezembro de $1948 . \quad$ Disponível em: <http://portal.mj.gov.br/sedh/ct/legis_intern/ddh_bib_inter_universal.htm>. Acesso em 06 mar.2014.

ORGANIZAÇÃO DAS NAÇÕES UNIDAS (ONU). Pacto Internacional sobre os Direitos Econômicos, Sociais e Culturais das Nações Unidas. Disponível em: <http://www.dhnet.org.br/direitos/sip/onu/doc/pacto1.htm>. Acesso em 19 maio. 2014.

PEÑA, Chacón Mario. El principio de no regresión ambiental en la legislación y jurisprudência Costarricense. In: PEÑA, Chacón Mario (Org.). EI Princípio de no Regresión Ambiental em el Derecho Comparado Latinoamericano. São José/Costa Rica: PNUD, 2013.

PEÑA, Chacón Mario (Org.). El Princípio de no Regresión Ambiental em el Derecho Comparado Latinoamericano. São José/Costa Rica: PNUD, 2013.

PRIEUR, Michel. O Princípio da "Não Regressão" no Coração do Direito do Homem e do Meio Ambiente. In: Revista Novos Estudos Jurídicos, vol. 17, n. 1, p. 06-17/jan-abr. 2012. Disponível em: <www.univali.br/nej>. Acesso em: 23 ago, 2013.

PRIEUR, Michel. Princípio da proibição de retrocesso ambiental. In: Comissão de meio ambiente, defesa do consumidor e fiscalização e controle. Princípio da proibição de retrocesso ambiental. Brasília: Senado Federal, 2012.

SENADO FEDERAL. Conferência Rio-92 sobre o meio ambiente do planeta: desenvolvimento sustentável dos países. Disponível em <http://www.senado.gov.br/noticias/Jornal/emdiscussao/rio20/ario20/conferencia-rio-92-sobre-o-meio-ambiente-do-planeta-desenvolvimentosustentavel-dos-paises.aspx>. Acessado em: 11 set, 2014

Submetido em: Setembro/2014

Aprovado em: Outubro/2014 